\title{
Economics
}

2017; 6(6): 58-64

http://www.sciencepublishinggroup.com/j/eco

doi: $10.11648 /$ j.eco.20170606.11

ISSN: 2376-659X (Print); ISSN: 2376-6603 (Online)

\section{Determinants of Tax Revenue in Ethiopia}

\author{
Neway Gobachew*, Kenenisa Lemie Debela, Woldemicael Shibiru
}

Department of Accounting and Finance, Jimma University, Jimma, Ethiopia

Email address:

gobachew27n@gmail.com (N. Gobachew)

${ }^{*}$ Corresponding author

\section{To cite this article:}

Neway Gobachew, Kenenisa Lemie Debela, Woldemicael Shibiru. Determinants of Tax Revenue in Ethiopia. Economics.

Vol. 6, No. 1, 2018, pp. 58-64. doi: 10.11648/j.eco.20170606.11

Received: November 15, 2017; Accepted: February 6, 2018; Published: February 12, 2018

\begin{abstract}
Fiscal deficit is the core issue of most of the developing countries over the past several decades. The reason behind the large increase in fiscal imbalance is the rapid expansion in expenditure and low revenue collection. Hence, efficient tax system is crucial for these countries. Since Ethiopian is one among developing countries, pattern of tax revenues and economic growth across country has become a significant concern. Due to aforementioned deficiencies, Ethiopia struggles with budget deficits for a long time. The focus of this paper is to identify determinants of tax revenue in Ethiopia by using a secondary data and multiple variables regression model using OLS method. Quantitative research method was employed on time series data set for the years 1999/00 to 2015/16. Both descriptive statistics and econometric tools were employed to analyze and present the data collected from concerned bodies. The finding reveals that, industry sector share to GDP, per capita income and trade openness as measured by share of export and import to GDP have significant positive effect on tax revenue whereas; agriculture sector share to GDP and annual rate of inflation have significant and negative effect on tax revenue as measured by share of tax revenue to GDP.
\end{abstract}

Keywords: Determinants, Ethiopia, Tax Revenue

\section{Introduction}

Economic development is the main objective that all developing countries are striving for. Ethiopia as one of the fast growing country has set astonishing goals to be achieved and tremendous results were achieved in Growth and Transformation Plan (GTP 1) and the country is pushing forward with the remaining to be achieved in Growth and Transformation Plan (GTP 2).

Mere demand for development is not an end in itself unless such nations are not endowed with resources required to do so. While most developing countries like Ethiopia are resource blessed, they face a problem of fiscal deficit, which make them to depend on foreign assistance to finance their development program. Therefore, better mobilization of internal resources could help to reduce the fiscal deficit, and to better control the process of economic development and reduce poverty.

According to Karagoz (2013) fiscal deficit is the core issue of most of the developing countries over the past several decades. The reason for this rapid fiscal imbalance according to the author is the rapid expansion in expenditure and low revenue collection practice in these nations. To this end, the role of taxation in many developing countries has been emphasized as an instrument of economic growth and development. Pius and Raymond (2014) explained the main function of a tax system is to raise enough revenue to finance essential expenditures on the goods and services provided by government. According to Chaudhry and Munir, (2010) since resources of the society is scarce, governments expend more by soliciting funds from different sources as; borrowing, receipt of aid, printing of money and taxation. The author further added that, raising tax revenue is one means of transferring resources from the private to public sector.

NEPAD-OECD African Investment Initiative Report dated (2009) cited that taxation is central to the current economic development agenda. The report witnessed that tax provides a stable flow of revenue to finance development priorities, such as "strengthening physical infrastructure, and is interwoven with numerous other policy areas, from good 
governance and formalizing the economy, to spurring growth." But evidences indicated that developing countries are not financing their development mainly from taxation. For instance, According to IMF report (2016) the ratio of taxation revenue to GDP in Ethiopia was 23.47 percent which is lower the standard of East African Countries (29\%) and that of Sub-Saharan African countries (26\%). As a result, the increasing budget deficit has raised concerns regarding the sustainability of government debt, the control of inflation, exchange rate control and the fiscal program in general. Suri and Shome, (2013) also witnessed that as in many developing countries, tax revenue in Ethiopia is too low to finance government expenditure which in turn resulted in continuous budgetary deficits. For instance, world bank report dated (2014) indicated that general government budget deficit increased to 2.6 percent of GDP in 2013/14, compared to 1.9 percent of GDP in the previous year whereas, government revenues declined from 14.3 percent to 14.0 percent of GDP in 2013/14. In addition, World Bank Report (2013) indicates that Ethiopia's tax revenue to GDP ratio was $23.5 \%$ expected $25 \%$, which is less than sub-Saharan country (26\%). A number of factors have mentioned to contribute to such weak contribution of taxation to the economic progress of developing nation. For instance Karagoz (2013) posited the share of agriculture and industry sectors to GDP, foreign debt stock, economy monetization rate, and rate of urbanization as main determinants of tax revenue in Turkey. In a similar fashion, Muibi \& Sinbo (2013) analyzed forty two years data and come up with the conclusion that the level of change in income, rate of inflation and exchange rate are the main determinants of tax revenue in Nigeria. Velaj \& Prendi (2014) also witnessed that inflation; unemployment and GDP are the significant determinants of tax revenue in Albania. But relying on these factors and generalizing to Ethiopian context leads to wrong conclusion as there are peculiarities in social, economic, political and technological structures among countries.

Thus, the basic question that must be answered by researchers in Ethiopia has to be; what are the significant factors that resulted in such trifling contribution of tax to national development? Hence, the main purpose of this study is to investigate the main determinants of tax revenue in Ethiopia that is believed to narrow the prevailing literature gap on the issue and be used as a benchmark for policy implications of government and other concerned bodies.

\section{Statement of the Problem}

Development program of many developing countries was bottlenecked by low collection of tax revenue. Tax revenue has vital importance for the sustainability of developed and developing countries because of the following reasons. Firstly, taxation is the main source of central government revenue, even in aid-dependent low income countries. Secondly, taxation aims to meet the social and public needs by providing public goods and services. Thirdly, government need tax revenue to establish armed forces and judicial systems to ensure the secure environment and justice of the society. According to Bhushan and Samy, (2012) global economic crisis coupled with uncertainty and instability of aid flows has given due attention for governments to look for stable and sustainable modes of development finance. In addition, excessive reliance on foreign financing may in the long run leads to problems of debt sustainability. As a result, developing countries will need to rely substantially on domestic revenue mobilization Gupta, (2007). One way of mobilizing domestic resource is achieved through rising of revenue from taxation.

According to the World Bank report of 2016 tax revenue (\% of GDP) in Ethiopia was last measured as less than $23 \%$ which is even less than the average value of sub Saharan country that has $26 \%$ of GDP. As a result, Ethiopia has faced budget deficit every year since government expenditure exceed government revenue. To tackle this problem, the government impose tax (direct and indirect), among others; as major and important sources of public revenue. However, Tadele, (2015) forwarded that this imposition of tax couldn't still brought the required result due to a number of reasons such as lack of clear understanding about the tax system by the tax payers, tax payers inability to comply with tax obligation, hostility between tax payers and tax officials, negative attitude of tax payer towards the tax system. For these reasons, the actual amount of tax couldn't be collected properly.

According to World Bank (2015) report 24\% of GDP to finance investment requirement is being solicited from loans and grants. Furthermore, Tadele (2015) indicated that although the overall economic performance of Ethiopia, measured by growth in real GDP, between 2003/04- 2010/11, registered an average annual growth rate of $11.4 \%$, and the contribution of tax revenue to GDP in 2010/11 is about $11.5 \%$ the ratio was proved to be low compared to other developing countries such as Botswana (35.2\%), Djibouti (20\%) Kenya (18.4\%). According to Workineh, (2016) the role of tax revenue is imperative in bringing economic development, where its working or efficiency is determined by different socio economic and political factors.

There is no consensus among literatures as far as the determinants of tax revenue are concerned. For instance, Eltony (2002) found foreign aid and foreign debt to have positive influence on tax revenue, whereas; Gupta (2007) indicated that both have negative effect on tax revenue. As far as the relation between tax revenue inflation rates is concerned, Mahdavi (2008) indicated that tax revenue is negatively affected by inflation. Tesfaye (2015) forwarded that, foreign direct investment to GDP percentage negative significant influence on tax revenue, but Belay (2015) in his study reveals that foreign direct investment has significant positive relationship with tax revenue.

As far as the knowledge of the researchers is concerned, no comprehensive research has been conducted to assess the determinants of tax revenue and bridge the gap in the existing literature and the existing literatures indicated inconclusive finding as far as the determinants of tax revenue is 
concerned. Therefore, conducting research with could fill the gap of such contradicting findings is timely and worth taking. Hence, research is aimed at is assessing the determinants of tax revenue performance in Ethiopian.

\section{Objective of the Study}

The major objective of this study is to identify the determinants of tax revenue in Ethiopia.

\section{Significance of the Study}

The study provide feedback to the Ethiopian government in making policy measures to be under taken regarding those determinants, and also serves Ethiopian revenue and customs authority in improving its performance in tax collection and in making future policy recommendations. In addition, it is expected to help serve as an input for the upcoming researchers to further investigate the points under considerations.

\section{Empirical Literatures}

Several empirical studies have looked into determinants of resource mobilization at regional level. Teera (2002), used time series data on Uganda to examine the determinants of tax revenue share in that country. He used the Augmented Dickey Fuller (ADF) and the Error Correction Model (ECM) and found that, there is a positive relationship between per capita income and total tax revenue as well as income taxes. This finding lends support to the hypothesis that, as countries develop tax bases develop more than proportionately to the growth in income. Eltony (2002) examined the determinants of tax revenue shares and constructed an index of tax effort for the sixteen Arab countries. The results suggest that the main determinants of tax share of GDP for Arab countries are; per capita income, share of agriculture in GDP and share of mining to GDP. Other important determinants are share of exports and imports and in the non-oil Arab countries, the outstanding foreign debt was found significant and positively related to the tax share. Agbeyegbe, Stotesky \& Woldemariam (2004) investigated the relationship between the tax revenue, trade liberalization and changes in the exchange rate using a panel data set of 22 sub-Saharan countries and found that trade liberalization, agricultural share, industrial share, government consumption, and terms of trade exert have positive effect on total tax revenue, and inflation exerts a negative effect. Gupta (2007) investigated revenue performance of large set of developing countries over 25 years. He found that several structural factors like per capita GDP, share of agriculture in GDP and trade openness are significant and strong determinants of revenue performance. His findings showed strong negative and significant relationship between agriculture share and revenue performance. It is estimated that a $1 \%$ increase in the share of agriculture sector could reduce revenue performance by as much as $40 \%$ percent. The results indicate that although foreign aid improves revenue performance significantly, debt doesn't. Among the institutional factors, he found corruption has significantly negative effect on revenue performance. Political and economic stability are other effective factors, but only across certain specifications. On the other hand, countries that put greater emphasis on tax income, profits and capital gains, perform better. Mahdavi (2008) used the advanced estimation techniques with an unbalanced panel data for 43 developing countries for the periods 1973-2002. The results showed that while agriculture sector share has positive effect, aid and non-tax revenue have negative effect on tax revenue. Trade sector share had a positive effect while old-aged portion of population showed negative association with both income and sales tax. Furthermore, extents of urbanization and literacy rate have positive effect. While population density, monetization and inflation rate remained negatively correlated, inverse of GDP per capita was strongly and negatively correlated with the level of taxation. Chaudhry and Munir (2010) attempted to analyze empirically the determinants of low tax revenue in Pakistan by employing time series econometric techniques over the periods 1973-2009. They investigated whether economic policies, external variables and social indicators along with elements of tax base can account for part of the variation in the tax revenue performance. Their empirical results suggest that; openness, broad money, external debt, foreign aid and political stability are the significant determinants of tax efforts in Pakistan with expected signs. The results also indicates that narrow tax base, more dependence on agriculture sector, foreign aid and low level of literacy rate are the reasons for low tax revenue in Pakistan. Ahmed and Mohammed (2010) attempted to search the determinants of tax buoyancy of 25 developing countries. Their study revealed that growth in import and manufacturing sector has positive impact on growth of tax collection. The research also found that monetary growth has positive influence on tax collection. Finally increase in budget deficit has positive influence on tax collection by demanding more resource mobilization from the governments, however, at the same time the growth in grants inversely influences tax collection because government in developing countries avoids unpopular steps of imposing taxes for domestic resource mobilization. Anware (2014) researched on the determinants of tax revenue performances in case of Ethiopian Revenues and Customs Authority. For the period 1990/91 to 2010/11 and identified six basic variables that determine tax revenue mainly; industry, agriculture, inflation, GDP per capital income, export and import he concluded that structural factors such as exports of goods and services (\% of GDP) and import of goods and service (\% of GDP) significantly affect tax revenue performance. Velaji \& Prendi (2014) analyzed the determinants of tax revenue in case of in case of Albania by taking unemployment, inflation, GDP and Imports. Pearson correlation and regression analysis was applied and the finding revealed that all the independent variables significantly affect tax revenue with the exception of import of goods and services. 


\section{Research Design and Methodology}

Quantitative approach to research was used to indicate what would happen to tax revenue if the independent variables to the study change. To accomplish the purpose of the study researchers employed secondary data ranging from 2000 - 2016 collected from different local and international organizations like; Ministry of Finance and Economic Development (MoFED), Ethiopian Revenue And Custom Authority (ERCA) National Bank of Ethiopia (NBE), Ethiopian Investment Agency (EIA) and the Ethiopian Economic Association (EEA) database, and World Bank (World Development indicators (WDI)). Ordinary Least Squire (OLS) with multiple variables was used to assess the relation between dependent and independent variables. Data analysis, interpretation and presentation was done using descriptive statistics, inferential statistics such as; regression, correlation and ANOVA. The assumptions of classical linear regression were tested and no serious problem was found.

\section{Model Specification}

The following model was developed based on previous literature.

$$
\begin{aligned}
& \text { TR }=F(G D P, \text { OPNS, INFLN, FDI, PD, AGRI, INDU, SERV }) \\
& \text { TR }=\alpha+\beta_{1} \text { PERC }+\beta_{2} \text { OPPS }+\beta_{3} \text { INFLN }+\beta_{4} \text { FDI }+ \\
& \beta_{5} \text { AGRI }+\beta_{6} \text { INDU }+\beta_{7} \text { SERV }+\beta_{8} \text { PD }+\varepsilon_{\mathrm{t}} \text { Where, TR is } \\
& \text { Tax Revenue as Percentage of GDP. } \\
& \text { Where, } \alpha \quad \text { is Intercept } \quad \text { Term } \\
& \beta_{1}, \beta_{2}, \beta_{3} \ldots \beta_{8} \text { are Coefficients, and }
\end{aligned}
$$

$$
\begin{aligned}
& \text { LPERC = Per Capita Income } \\
& \text { OPPS }=\text { Trade Openess as Measured by Share of Export and Import to GDP } \\
& \text { INFLN = Annual Inflation Rate } \\
& \text { FDI = Foreign Direct Investment as Percentage of GDP } \\
& \text { AGRI = Agriculture Sector Share to Total GDP } \\
& \text { INDU = Industrial Sector Share to GDP } \\
& \text { SERV = Service Sector Share to GDP } \\
& \text { PD = Public Debt as Percentages of GDP } \\
& \varepsilon=\text { Error Variable }
\end{aligned}
$$

\section{Data Analysis}

\subsection{Descriptive Statistics}

The following table indicates the descriptive statistics of determinants of tax revenue in Ethiopia.

Table 1. Descriptive Statistics.

\begin{tabular}{llllll}
\hline \multicolumn{6}{l}{ Descriptive Statistics } \\
\hline \multicolumn{1}{l}{ N } & Minimum & Maximum & Mean & Std. Deviation \\
\hline AGRI & 17 & 34.3410 & 46.7221 & 41.429546 & 3.4601924 \\
FDI & 17 & 11.3000 & 21.0000 & 14.390000 & 2.4674379 \\
PERC & 17 & 11.2743 & 19.6000 & 14.540780 & 2.6003727 \\
INDU & 17 & 8.2190 & 19.6547 & 12.656908 & 2.6572812 \\
INFLN & 17 & -10.7734 & 55.2413 & 12.037441 & 15.2563531 \\
OPPS & 17 & 7.7384 & 51.0508 & 23.388970 & 15.4215207 \\
TR & 17 & 8.7326 & 23.4657 & 13.391545 & 4.4960757 \\
\hline
\end{tabular}

Source: Data Collected from NBE, ERCA and MOFED; SPSS Output

From the descriptive statistics result the average performance of tax revenue collection in percentage of GDP at constant market price, of 1999/00-2015/16 period found to be $13.39 \%$ which relatively indicate the poor performance as compared to average of sub-Saharan countries for the same period which is $17.46 \%$ IMF (2016). The maximum and minimum values of TR percentage were 23.466 and 8.733 respectively with standard deviation of 4.496 .
With regard to agricultural share of GDP at constant market price, the average share of this sector was 41.43 percent which indicate the overall high share of this sector in the economy; the minimum share is 34.34 percent of $2015 / 2016$ whereas the maximum share of this sector is 46.72 percent in 1999/2000. However its share to GDP has decreased. This shows that the countries plan to transform to industry is promising and on the good truck. The mean value and standard deviation of industry share to GDP is 12.66 and 2.66 percent respectively. This implies that industrial sector contributes lowest percentage to GDP. This is attributed to the fact that Ethiopia's economy is largely dominated by agriculture share followed by service sector.

As far as FDI is concerned, its mean value and standard deviation are 14.39 percent and 2.47 respectively with the minimum and maximum value of 11.3 and 21 percent respectively. This value implies the presence of higher variation in the amount of foreign direct investment in Ethiopia during the study period. Inflation as measured by annual average rate for 1999/00-2015/16 period found to be $12.04 \%$ on average which indicate the overall good acceptable rate in the economy with higher standard deviation of 15.26 percent.

In case of trade openness measured by import plus export as percentage of GDP at constant market price, of 1999/00-2015/16 period found to be 23.39 percent on average which implies the 
overall low performance as a result of low movement of internationally traded goods entering into and departing from a country as compared to average of sub-Saharan countries which is $26.86 \%$ IMF $(2015 / 16)$ report. There were high difference between the maximum trade openness in percentage of GDP
51.05 percent in year 2015/16, and Minimum trade openness in percentage of GDP of 7.74 percent in year 2000/01 when the economy performs less. This shows country's performance in international trade was not good.

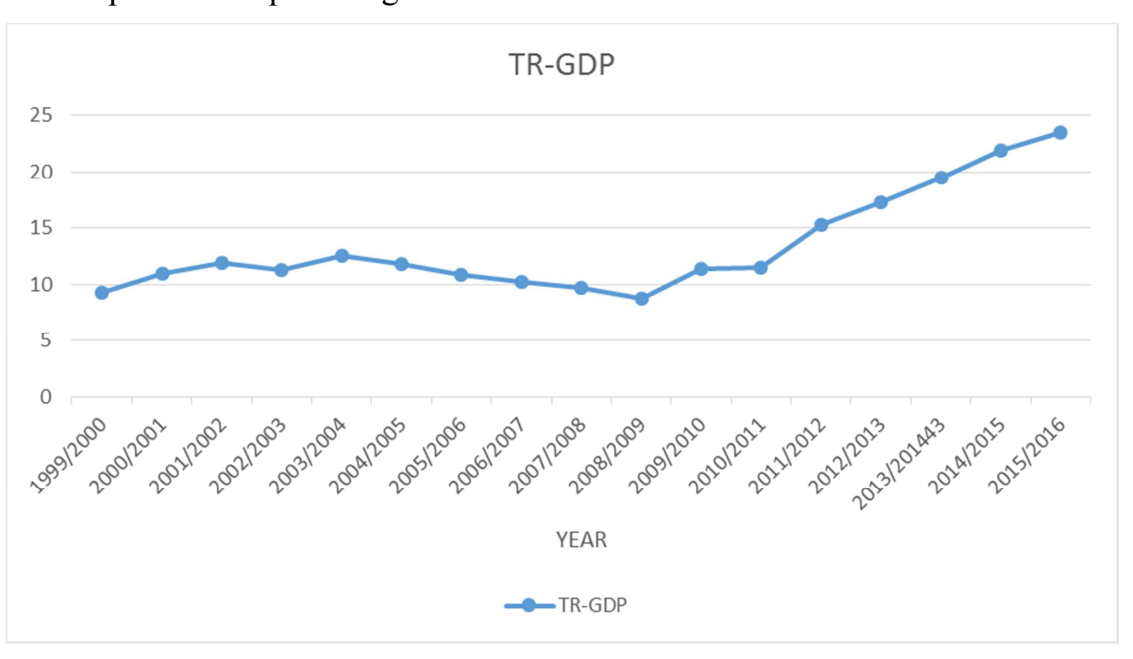

Source: National Bank of Ethiopia staff computation

Figure 1. Time series tax revenue share to GDP from 1999/2000 to 2015/16.

As it can be observed from figure 1, the trend of percentage of tax revenue share to GDP shows ups and downs i.e. not stable during last 17 years. It increases at some years and decreases at some other years. For example it has highly increased during 2003/2004 due to introduction of value added tax (VAT) in 2003 which have increased the tax base and this in turn resulted in generation of higher amount of tax revenue. In addition to this, the country's exports have also been growing strongly, averaging about 25.1 percent per annum since 2003/04. While coffee remains the largest source of merchandize export earnings, non-traditional exports have registered faster growth. Indeed, the continued rapid expansion of both these economies is likely to sustain the growth in Ethiopia's exports in the medium term. Ethiopia has also experienced strong economic growth in recent years with real GDP growth at or near double digit levels since 2003/04 AEO (2016).

However, during 2008/2009 tax revenue share to GDP has shown decrement because of global financial crisis which in turn affected cross border import and export of goods and services. This in turn resulted in reduction of the amount of tax to be collected from international trade with the rest of the world. In addition to this the above graph also indicates that tax revenue share to GDP is increasing sharply since 2010/11 because the first GTP has helped to ensure sustainability of Ethiopia's economic development and brought significant changes and improvements particularly in areas of agricultural productivity, industrial development, and expansion of infrastructure ADB (2012/13).

\subsection{Correlation and Regression Analysis}

\subsubsection{Correlation Analysis Between TR and Independent Variables}

In table below, the correlation analysis was undertaken between tax revenue share to GDP and explanatory variables; per capita income, agriculture sector share to GDP, industry sector share to GDP, foreign aid share to GDP, trade openness share to GDP, annual inflation rate and foreign direct investment share to GDP.

Table 2. Correlation Matrix between TR and Independent Variables.

\begin{tabular}{|c|c|c|c|c|c|c|c|c|}
\hline & & TR & AGRI & INDU & INFLN & OPPS & PERC & FDI \\
\hline \multirow{7}{*}{ Pearson Correlation } & TR & 1 & & & & & & \\
\hline & AGRI & -0.773 & 1 & & & & & \\
\hline & INDU & 0.696 & -0.686 & 1 & & & & \\
\hline & INFLN & -0.121 & 0.198 & 0.198 & 1 & & & \\
\hline & OPPS & 0.829 & -0.423 & 0.318 & 0.182 & 1 & & \\
\hline & PERC & 0.733 & -0.304 & 0.297 & 0.11 & 0.775 & 1 & \\
\hline & FDI & 0.704 & -0.508 & 0.648 & -0.212 & 0.606 & 0.455 & 1 \\
\hline
\end{tabular}

Source: Correlation Output of Data Collected

The correlation output indicated that there is a positive correlation between TR and industry share, trade openness, per capita income and foreign direct investment while, there is a negative correlation between TR and agriculture share to GDP and inflation rate. 
Table 3. Regression Analysis Results for TR and Explanatory Variables.

\begin{tabular}{|c|c|c|c|c|c|}
\hline \multicolumn{6}{|c|}{$R=0.989$ R Square $=0.979$ Adj. $R$ Square 0.966 Std Error of Estimate $=0.826786$} \\
\hline \multicolumn{6}{|c|}{ Durbin-Watson $=1.990 \mathrm{~F}=77.192 \mathrm{P}=0.000$} \\
\hline \multirow{2}{*}{ Model } & \multicolumn{2}{|c|}{ Unstandardized Coefficient } & \multirow{2}{*}{$\begin{array}{l}\text { Standardized coefficients } \\
\text { Beta }\end{array}$} & \multirow{2}{*}{ t } & \multirow{2}{*}{ sig } \\
\hline & B & Std.Error & & & \\
\hline (Constant) & 13.342 & 5.33 & & 2.503 & 0.031 \\
\hline AGRI & -0.404 & 0.089 & -0.311 & -4.541 & 0.001 \\
\hline INDU & 0.466 & 0.129 & 0.275 & 3.618 & 0.005 \\
\hline INFLN & -0.04 & 0.016 & -0.137 & -2.594 & 0.027 \\
\hline PERC & 0.63 & 0.236 & 0.199 & 2.672 & 0.023 \\
\hline FDI & -0.126 & 0.142 & -0.069 & -0.887 & 0.396 \\
\hline OPPS & 0.146 & 0.026 & 0.522 & 5.596 & 0.000 \\
\hline \multicolumn{4}{|c|}{ a. Dependent Variable: TR } & & \\
\hline
\end{tabular}

Source: SPSS Output for Data Collected from NBE, MOFED and ERCA

\subsubsection{Model Fitness}

As shown on the above table the explanatory power of the tax revenue determinants in terms of $\mathrm{R}^{2}$ is $97.8 \%$ which implies that around 98 percent of variation in tax revenue is explained by this model and this is good in time series data as explained by Brook (2008). In this study, $\mathrm{P}>\mathrm{F}=0.000$ which is less than 0.01 . Thus, we can conclude that the model is adequate at the $1 \%$ level of significance.

Share of Agriculture Sector to GDP

Agriculture sector share in GDP as depicted in the above regression equation has negative and significant effect on tax revenue at $1 \%$ significance level. This value implies that $1 \%$ increase in agriculture share to GDP results in 0.331 decrease in tax revenue share to GDP keeping other things constant. This is mainly due to the low taxable capacity associated with the bigger agricultural share in GDP. This result is consistent with the finding of Eltony (2002), Gupta (2007), and (Workneh2016).

\section{Share of Industry Sector to GDP}

The result indicated that share of industry to GDP has statistical significant positive effect on tax revenue at significance level of $1 \%$. The result depicted that one percent change in the share of industry to GDP would resulted in $27.5 \%$ change in tax revenue in Ethiopia. The finding is consistent with the results of Eltony (2002) which proposed that since manufacturing enterprises are typically easier to tax than other agriculture activities because business owners typically keep better books and follow better accounting practices and manufacturing can generate larger taxable than agriculture. The result is also in line with the findings of Teera (2003), Mahdavi (2008), Ahmad \& Mohammed (2010), Karagoz (2013) and (Basirat et al. 2014).

\section{Inflation Rate}

Inflation as measured by annual headline rate of inflation and taken as measure of macroeconomic instability is found to have significant effect on tax revenue in Ethiopia. The result indicated that inflation has statistically significant positive effect on tax revenue at 5\% significance level. More specifically, a $1 \%$ increase in inflation level would result in $13.7 \mathrm{~m} \%$ decrease in tax revenue. This is attributed to the fact that increase in cost of living associated with the loss of purchasing power of money, which ultimately could lead to tax evasion by tax payers and reduce real value of tax collected due. Moreover, the increase in price level would increase the informal economy which in turn is less taxed. The finding supports the theoretical and empirical evidences prevail on the relationship between tax revenue and inflation.

\section{Trade Openness Share to GDP}

Openness degree, measured as the share of exports and imports in GDP, also have significant impact on tax revenues. It is considered as an indicator of liberalization level of the economy. In developing countries, the international trade sector is typically the most monetized sector of the economy. Entrance and exit to the country takes place in specified locations. Trade liberalization in Ethiopia can be classified into export promotion and import substitution. Ethiopian government eliminated restriction on exporter to promote the export and have trade surplus. In line with this, the result reveals that openness has positive relationship with tax revenue in Ethiopia.

Per Capita Income

The model shows that tax revenue is positively and significantly influenced by gross domestic product per capita income. More specifically, a 1\% increase in real GDP per capita income results in approximately raise in tax revenue percentage of GDP by 0.20 percent, other things remain constant. In Ethiopia's tax system is progressive as clearly stated on tax proclamation number 286/2002 which means a person who get high income will pay high tax under different tax schedules like personal income tax, rental income tax, business income tax and other incomes so theoretically an increase in per capita income will leads to high tax revenue. The finding is also in consistent with priori findings as Mahdavi (2008), and (Karagoz, 2013).

\section{Foreign Direct Investment}

Foreign direct investment (FDI) is a category of crossborder investment in which an investor resident in one economy establishes a lasting interest in and a significant degree of influence over an enterprise resident in another economy. As current study shows the relationship between tax revenue and foreign direct investment is positively related and statically significant. 


\section{Conclusion}

The analysis indicated that, share of tax revenue to GDP is very low, which imply that domestic resource mobilization through taxation is at an infant stage in Ethiopia. The output revealed that annual rate of inflation and agriculture share to GDP were found to have statistically significant and negative effect on tax revenue. In contrast, trade openness, industry sector share to GDP and per capita income were found to have statically significant and positive effect on tax revenue. Policy changes and occurrence of natural calamities has resulted in acute shortage of agricultural food production since recent years the country come to face higher inflation. This made tax payers to put their tax liability a side and began to worry about satisfaction of their daily consumption, owing to loss of purchasing power of money. Empirical findings further revealed that structural factors, macroeconomic condition and external sector are the main policy instruments for tax revenue in Ethiopia. The result indicated that industrial sector contributes a lot to tax revenue whereas; agriculture sector contributes low to tax revenue. Although tax revenue performance in Ethiopia shows promising trend since a recent past, its GDP ratio remained low, indicating further that enhancing tax revenue be at the heart of policy makers.

\section{References}

[1] Agbeyegbe, T., J. G. Stotesky and A. Woldemariam, 2004. Trade liberalization, exchange rate changes, and tax revenue in Sub Saharan Africa. IMF Working Paper 04/178: 1-32.

[2] Ahmed, M., \& Mohammed, S. (2010). Determinant of Tax Buoyancy: Empirical Evidence from Developing Countries. European Journal of Social Sciences - Volume 13, Number 3 (2010) 408 .

[3] Alemayehu, G., \& Abebe, S. (2005). Taxes and tax reform in Ethiopia, 1990-2003. United Nations University World institution of development research paper No.2005/65.

[4] Anware, N. (2014). Determinants of tax revenue performances in Ethiopia:mini research paper.

[5] Belay, Z. (2015). Determinants of tax revenue performance in Ethiopia federal government.

[6] Bhushan, A., \& Sami. (2012). Aid and taxation: Is SubSaharan Africa different? North South Institute Research Report.

[7] Basirat, M., F. Aboodi and A. Ahangari, 2014. Analyzing the effect of economic variables on total tax revenues in Iran. Asian Economic and Financial Review, 4(6): 755-767.

[8] Brooks C. (2008). Introductory econometrics for finance, 2nd $e d n$. New York: Cambridge university press.

[9] Chaudhry, I., \& Munir, F. (2010). Determinants of low tax revenue in pakistan. journal of social science, 30(2) 439-452.

[10] Eltony, N. (2002). Evaluation of tax revenue in Arab countries. Kuwait: API publication.
[11] Gupta. (2007). Determinants of tax revenue effort in developing countries. Washington: IMFworking paper 70/184.

[12] International Monetary Fund (2016). IMF Executive Board Concludes 2016 Article IV Consultation with the Federal Democratic Republic of Ethiopia. Press Release No. 16/443. Washington, D. C. 20431 USA.

[13] Karagöz, K. (2013). Determinants of tax revenue: Does sectorial composition matter? Journal of finance accounting and management, 4(2),50-63.

[14] Levin, J. (2008). Determinants of tax revenue in sub-Saharan Africa. Journal of Business and economics, 1-21.

[15] Mahdavi, S. (2008). The level and composition of tax revenue in developing countries. International review of economic and finance.

[16] Misrak T. (2008). Ethiopian tax accounting. Finfine: Aster Nega publishing PLC.

[17] Muibi, O., \& Sinbo, O. (2013). Macroeconomic Determinants of Tax Revenue in Nigeria (1970-2011). World Applied Sciences Journal 28 (1): 27-35, 2013 ISSN 1818-4952. IDOSI Publications, 2013 DOI: 10.5829/idosi.wasj.2013.28.01.1189.

[18] NEPAD - OECD (2009) African Investment Initiative. Taxation for Investment and Development: An overview of policy challenges in Africa.

[19] OECD (2006), Tax Policy Reforms in Turkey, Centre for Tax Policy and Administration (CTPA), Organization for Economic Cooperation and Development. OECD, Online database.

[20] Pius, K., \& Raymond, E. (2014). Factors affecting tax revenue in pakistan. International Journal of Advanced Research, volume2, issue 2,449-458.

[21] Tadele B. (2015). Analysis of Tax Buoyancy and Its Determinants in Ethiopia (Cointegration Approach) Journal of Economics and Sustainable Development Vol.6, No.3, ISSN 2222-1700 (Paper) ISSN 2222-2855 (Online) www.iiste.org.

[22] Tanzi, V. (1991). The impact of macroeconomic policies on the level of taxation (and on the fiscal balance) in developing countries. in Eglar public finance in developing countries(116-132). Edward: Eglar publishing Ltd.

[23] Teera, J. (2002). Tax performance: A comparative study. Department of Economics, University of Bath Working paper.

[24] Tesfaye A. (2015). Determinants of Tax Revenue in Ethiopia. A Master's Thesis at Addis Ababa University Department of Accounting and Finance.

[25] Velaj, E. \& Prendi, L. (2014). Tax Revenue - The Determinant Factors- the Case of Albania. European Scientific Journal September 2014 /SPECIAL/ edition Vol.1 ISSN: 1857-7881 (Print) e - ISSN 1857-7431.

[26] Workneh, A. (2016). Determinants of tax revenue in Ethiopia (Johansen co-integration approach). Journal of Business, Economics and Management, 3(6):69-84.

[27] World Bank. (2013). "Global Monitoring Report 2013, Policies and Actions for achieving the MDGs and related outcomes. Washington DC: World Bank.

[28] world Bank. (2015). World Development Indicators. Washington D.C. World bank. 